\title{
New Innovation in English Language Teaching: Revealing Concepts and Applications of ECO-ELT
}

\author{
Jepri Ali Saiful* \\ Department of English Education, University of Muhammadiyah Surabaya, Indonesia \\ jeprialisaiful@fkip.um-surabaya.ac.id \\ *corresponding author
}

\author{
Article History \\ Received: 20 February 2020 \\ Reviewed: 9 March 2020 \\ Accepted: 11 April 2020 \\ Published: 30 April 2020

\section{Highlights} \\ - Eco-ELT is the integration \\ of two fields of study; \\ Ecocriticism and English \\ Laguage Teaching (ELT) \\ - Eco-ELT believes that \\ literary works can be an \\ avenue to embed and \\ spread the virtues of loving \\ the environment or nature \\ to the students which at the \\ same time to build their \\ English language skills and \\ components. \\ - English teachers now have \\ a new and pivotal \\ responsibility to be "green" \\ moral agents, awaken self- \\ awareness and sense of \\ belonging to human beings \\ towards the nature through \\ language instructions.
}

\begin{abstract}
Nature is essential to our lives. Unfortunately, the widespread influence of modernism and industrial progress results to environmental pollution and destruction of the nature. Ecocriticism study is thereby projected to awaken self-awareness and sense of belonging to human beings towards the nature. This study is thus aimed to discuss and integrate the nature of Ecocriticism in English language teaching, particularly in the applications in lesson plans and teaching materials. The results show that Ecocriticism disseminates the issues of environmental crisis and the necessity of saving the nature and therefore taking the roles of literature to lead people virtue and right is necessary. English teachers is unequivocally became "green" moral agents. They have new responsibilities to use literature to not only teach English skills and components, but also to embed and spread the virtues of loving the nature to the students. Thus, the concept of Eco-ELT derived from the terms of Ecociticism and English Language Teaching (ELT) was coined and introduced. Eco-ELT worked on a basis postulate that literary works could be an avenue to teach English and ecology at the same time. The selections and applications of the literary works therefore mattered. This study provided samples and principles of designing eco-lesson plan and selecting and designing eco-teaching materials. Importantly, this study expounded the areas of eco-English materials necessary for English teachers.
\end{abstract}

Keywords: Ecocriticism, English Language Teaching, Environment, Eco-ELT

\section{Introduction}

The interdisciplinary study has recently witnessed profound increases in its form is Ecocriticism. The idea of which, as described by (Glotfelty, 1996) with the relationship between literature and the physical environment or ecology. It explores the natural environment with the complexities of human relationship in literature. Thus, essentially, the study of Ecocriticism brings an idea of embedding the virtues of loving the nature or Mother Earth to the human beings.

In practical field of Ecocritical teaching for instance, the explorations of the virtues of loving and saving the nature have set up within and beyond the classroom. Through given courses of "teaching literature to children" and "introduction to literature" in English Language Teaching (ELT) departments, future teachers have actually been aimed to be "green" moral agents. Of which they do not only teach the grammatical and language features of literary works but also discuss the issues of environmental crisis and the necessity of saving the nature to the students. In this case, the teachers disseminate and instill the sense of loving the environment 
in the classroom. Of which it is contributing to solve the conflict between man considering himself the superior over nature and nature which is the critical source of life on earth (Bahador \& Faghfori, 2014). This aims important and has to be brought into study.

Thus, the researcher proposes Eco-English Language Teaching or Eco-ELT in which studies the roles of English teachers to be "green" moral agent in the classroom. It combines the essence of Ecocriticism with the function of teachers as a role model and transformer. Hence, this research is aimed to explore the concepts of Ecocriticism and English Language Teaching (ELT) by giving theoretical elaborations on each of the study. This research is also aimed to give examples of practical applications of Eco-ELT in lesson plans and teaching materials. Besides, this research is expected to give significance contributions to the study of Ecocriticism and English Language Teaching (ELT). It is also expected to give practical guidance and understanding for English teachers and green schools to disseminate ideas of environmental conversation in education settings.

\section{Literature Review}

\section{Ecocriticism}

As (Glotfelty, 1996) says in his book entitled The Ecocriticism Reader; Landmarks in Literary Ecology, "If we are not a part of the solution, we are a part of the problem". This is somewhat reflects the his encouragement to literary readers and scholars at that time in the late 1990s, on the present issues of environmental crisis and conservation as results of great industrial revolutions took place in $18^{\text {th }}-19^{\text {th }}$ century in Europe and America. These issues are therefore further elaborated by a historian, Donald Worster. He says that man is now facing what socalled "global crisis". It is not because of how ecosystem functions, yet rather due to the ethical system function of men (Glotfelty, 1996). Thus, from both Glotfelty and Worster's statement, it is seen that the issue and spirit of ecology and its conservation has actually been echoed since century ago. Likewise, it was first coined in 1978 by William Rueckert in his essay "Literature and Ecology: An Experiment in Ecocriticism". Therefore, in this case, the study of relationship between physical environment and literature called Ecocriticism came into being.

This study transgresses disciplinary boundaries that take an earth-centered approach to literary studies. And therefore there are four key points need to be taken into account in understanding the study of Ecocriticism itself. These are:

1. Ecocriticism believes that human culture is tied with the physical world, of which it affects each other. And it is become a fundamental premise of Ecocriticism (Glotfelty, 1996).

2. Ecocriticism examines the connection between writers, texts, and ecosphere. Of which, based on Josep W. Maker's views (1972), it seeks the biological themes and the relationship revealed in literary works, attempted to find out the role of literature in the ecology of the human species (Glotfelty, 1996).

3. Ecocriticism is environmentally oriented developments in philosophy and political theory. It creates critical movements, ecofeminists, social ecologists, and environmental justice (Garrad, 2004).

4. Newborn of Ecocriticism explores and highlights the connection between ecology and numerous fields of study such as film, ethics, psychology, history, Native American Studies, literature and women's studies (Bahador \& Faghfori, 2014). 
Thus, as an interdisciplinary study, Ecocriticism welcomes newborn of ecocritical views in which to find ways of adding an environmental dimension in the respective disciplines, and education is no exception. Since 1992, the Association for the Study of Literature and the Environment (ASLE) has set up close relation between the study of ecology in literature and education. The ASLE conducts regular conferences on Ecocriticism studies including publishes articles on environmental education and activism. An ecosphere is therefore become an objective in the disciplines, to spread the essence of "green" moral agents of Ecocriticism. Of which it is become a fundamental background of ecocritical teaching.

The presence of ecocritical teaching itself is aimed to instill the consciousness mind of loving the environment and to construct deep level of self-awareness towards the nature in the classroom. Therefore, what so called "green" moral and "agents" here are described in alignment with the concept of deep ecology in literary theory of Ecocritcism. It means that the man takes big responsibilities to preserve the nature. He is neither superior nor in opposing with the nature. So it creates bio-centrism view in which man and nature are in unity and equality. Thus, the importance roles of man or human being in nature can be emphasized earth (Bahador \& Faghfori, 2014).

In this case, those roles of human beings in nature in lens of ecocritical teaching are reflected within the functions of schools and teachers as education executors. They are become the agents to frame "green" morals of the students through enjoyable discussions of ecology crisis and its conservation in literary works. The odes, tales, stories, poems, pastorals, folkloric songs are therefore utilized as teaching materials in the classroom, and eco-lesson plans are designed as frameworks of teaching learning process. As a result, the ecosphere in education settings is created and self-awareness of man on nature is embedded.

\section{English Language Teaching (ELT)}

In the twentieth century, the English language teaching has been subject to tremendous change. It is due to the development arts of teaching and language as in alignment with the human life. And it is aimed to become a reflection of real world that ought to vary as living, to find as many as approaches possible. As a result, a principle of "the nearer language teaching closes to real life, the more interesting it will be" come into being (Haycraft, 1978). In this case, the development of teaching and language themselves are therefore need to be various in the forms of approaches, methods and techniques, since the essence of them to dealing with the needs of human being. The presence of Grammar Translation Method (GTM), Suggestopedia, TaskBased Language Teaching and Content-based Instruction are the examples of the developments started from Classical Period to Post-method Era.

As the history of English Language Teaching (ELT) is developed within the period, the creativities of the teaching and language themselves are just close in line with it. Teaching listening using YouTube, teaching vocabulary using cue cards and the presence of blended learning for instance are just few examples of those creativities that appeared in the period of technology. Therefore, the language and teaching are somewhat inferred be essential to improve so that the teachers and students will have interesting and engaging learning atmosphere in the school. But still, since the essence of teaching and language deals with the needs of human being such as overcoming language barriers and boosting language competence, the development of them are needed to be focused with the issues of humanity. This is due to giving 
students' deep understanding of the real facts of society, culture and themselves as a function within social matrix. As it is expected that they will be linguistically and intellectually improved as well as emotionally and socially shaped. So, English Language Teaching (ELT) here will take a role as catalyst to provide simultaneous interconnection between the arts of teaching and language and the current issues of humanity, as to use the functions of literature in the classroom. To deal with, good lines of teaching learning process and activities in lesson plan as well as teaching materials need to be considered.

\section{Lesson Plan}

Framing lessons in teaching learning process is vital activity prior to the class begin. It is essential to give guidelines and structures of teaching as to prevent teachers' drying up when they are in the classroom. As instructions created, the lessons will be clear and the lines of teaching and learning activities will be dynamic. Therefore, in this case, teachers need to take account principles of instructions planning in order to frame good lesson plan and thus Murray \& Cristison (2011) describe eights of them:

-Instruction needs to build background knowledge.

-Instruction has to present new information in chunks of which learners can digest.

-Instruction includes teacher input which is comprehensible to students.

-Instruction needs to challenge the learners to always increase their level of language.

-Instruction provides opportunities for new skills and knowledge practice.

-Instruction provides feedback (from teachers and/or peers)

-Instruction provides a supportive environment.

-Instruction must be responsive to learning opportunities occur in the classroom.

Those eights principles are then coined with the information needed to plan a lesson or create a lesson plan. That information includes aims, objectives and learning outcomes, assessment data on pupils, scope and content, pedagogical methods, teacher's expectations, learning activities, homework, and differentiation of learning, progression in learning, other curricular links, resources, ancillary staff, risks, assessment, evaluation method, and review procedure (Haynes, 2007). As a result, with these combinations of principles instruction planning and lesson plan framework, the learning activities will be well structured and the students can achieve the standard competence.

\section{Teaching Materials}

Language teaching is different from teaching mathematics or sciences. Language teaching is more aimed to help learners to be proficient in L2 (target language). Therefore, it needs the outer circle of knowledge or concepts to ease achieving the target. This outer circle is in the form of social issues. Of which they are expected to give students understanding and conception on how knowledge gain from the classroom is implemented in the real life or the current situation, so that the students can play role as "true" human beings within social matrix. To start a discussion on the social issues themselves, appropriate textbook or teaching materials must be meticulously selected. It is because rarely does the textbook address social issues; instead it usually depicts the stereotypical families and cultures that tends to homogeneous (Murray \& Cristison, 2011). Therefore, in this case, teachers must find additional materials or supplementary 
materials that bring the issues of humanity in the classroom. These materials have to be integrated with the enhancement of English language skills and English components of the students.

In order to select good materials on language teaching, teachers need to consider five things which are:

-The materials must be engaging and fulfill the students' need.

-The materials must have lost of linguistics aspects and natural grammatical structure.

- The materials should be authentic and give impacts to the students.

-The materials provide enough area of assessment tasks.

-The materials should deal with certain humanity issues.

\section{The Application of Eco-ELT in Lesson Plan and Teaching English Material}

\section{Eco-ELT Lesson Plan}

As the study of Ecocriticism brings a message of embedding the virtues of loving Mother Earth. As of which is supported by the aims of ecocritical teaching, to instill the conscious mind of human beings to have sense of belonging to the nature and construct their self-awareness. In this case, "green" morals are therefore inferred become an essential target to be achieved. But, there is another critical point in which deal with ecological crisis must be considered, that is, the actions of environmental conservation themselves. This action determines whether the human beings apply the concepts of bio-centrism in a real life as a reflection of their responsibilities to the Mother Earth.

Dealing with these issues, teachers can use their roles as leader and facilitator. They can design a teaching learning process in lesson plan which supports ideas of loving the environment. For examples, they can create activities on ecological issues which combine both theoretical elaboration and the applications. Using the study of Ecocriticism in literary works, teachers can use poems which have environmental issues. They can use them as teaching materials of ecological activities in the classroom.

The example of activities in the classroom as follows: first, teachers explain and relate the topics of learning with the given eco-English poems to the students. Then, the teachers and students discuss the linguistics and grammatical features of the poems. Afterwards, teachers do vocabularies game in the poems with the students. At last, teachers ask the students to find the environmental issues depicts in the poems. And then the teachers question the students about the roles of human beings to address those issues. At this point, the students will get two important benefits. First, their linguistics competence is developed. Second, their selfawareness and knowledge on nature are increased. Importantly, with this model of learning also, a principle of instruction planning in lesson plan is reflected, that is, instruction needs to challenge the learners to always increase their level of language (Murray \& Cristison, 2011).

In addition to ecological classroom practice, if the students are in secondary or university level, the teachers can give further exercise in the form of a case study on ecological crisis. It is aimed to provide opportunities for new skills and knowledge practice for the students(Murray \& Cristison, 2011). And the example of the case study question that can be used is: "what your creative steps to conserve the nature, if you are chosen as a ministry of environment?". In this 
case, to answer this question, students are obligated to speak in English. It means that they have to deliver their ideas or thoughts towards ecological conservation in English, as to apply the inputs of language components they gained from the previous activities using poems; vocabularies, pronunciation, and grammar. Besides, the students are also asked to do a collaborative work with the groups to determine what steps and solutions to conserve the nature. Thus, it is inferred from this model of case study exercise, that students are shaped their critical thinking and abilities to speak English. They are also learnt to create a policy or action to address one of humanity problems; environmental crisis.

The above learning activities are the procedures in lesson plan; they still need other important aspects such as topics of learning, teaching approach, learning objectives and target of learners in order to form complete design of eco-English lesson plan. But, for the teachers who want to create their own design of eco-English lesson plan, they can follow some principles bellow:

- The eco-English lesson plan is created within the essences of Ecocriticism; embedding the virtues of loving the environment and self-awareness of human beings to the nature. Therefore, the learning process should reflect the activities that achieve the essences.

- The learning objects used in eco-English lesson plan must be from the products of literary works such as poetry, novels, short stories, folklore, films, video clips, scripts of plays or drama, scripts of theater, textbook, nature writing, traditional or modern songs, and so forth. Of which basically they are under the newborn of Ecocriticism study (Bahador \& Faghfori, 2014).

- The eco-English lesson plan brings two targets. First is achieving the learning objectives (English skills and components) and second is pursuing the aims of ecocritical teaching; to instill the consciousness mind of loving the environment and to construct deep level of selfawareness towards the nature in the classroom.

\section{Eco-English Teaching Material}

Supporting students' learning with diverse range of materials is part of important task for teachers, especially English teachers. With the array of English materials commercially available, teachers are easy to find kinds and forms of teaching materials that suitable for the topics of learning. These can be gotten from textbooks, pictures, newspapers, and magazines both online and offline. Of this case, teachers need to carefully select the materials that are going to be used. The teachers have to consider that the materials meet the principle of relevancy. It means that the materials have to reflect the social issues, by which students are learned to find the solutions or address humanity problems as to become a "true" human being within social matrix.

Of this consideration, the ecological materials are thus taken to be account. Teachers can select English materials that fulfil the ecocritical teaching's aims; instilling the consciousness mind of loving the environment and constructing self-awareness of human beings towards the nature in the classroom. And the English materials themselves are taken from the eco-literary works such as poetry, novels, short stories, folklore, films, video clips, scripts of plays or drama, scripts of theatre, textbook, nature writing, traditional or modern songs, and so forth. By which the teachers can teach the students the English linguistics aspects (English components and skills) and the ecological issues or crisis at the same time. Of this case, teachers are contributing 
to solve the conflict between man considering himself the superior over nature and nature which is the critical source of life on earth [2].

To provide guidelines for the teachers to develop or take appropriate eco-English materials used in their EFL or ESL classroom, some principles of selecting and developing ecoEnglish materials must be elaborated as well as the scope areas of eco-English materials themselves,. And each of them is described below:

\section{Principles of Selecting Eco-English Teaching Materials}

When teachers want to select eco-English materials for their classroom, they need to firstly consider the principles of selecting good materials on language teaching. Afterwards, they determine whether the materials are included as the classifications of Eco-English, as explained in the principles bellow:

- In most basic sense, the eco-materials must relevant to the topics of learning and the audiences.

- The eco-English materials can be taken from the online or offline resource of literary works.

- The eco-English materials have to be authentic and provide wide ranges of assessment areas.

- The eco-English materials must have or contain ecological issues of which related to human or humanity.

- The eco-English materials must construct the "green" knowledge by theory-creating process.

- The eco-English materials must be engaging and interesting.

\section{Principles of Developing Eco-English Teaching Materials}

When teachers intend to develop their own eco-English teaching materials, they can use principles bellow:

- The materials of eco-English must contain natural language.

- The materials of eco-English must provide wide rages of exposures on English skills and English components.

- The materials of eco-English must have or contain ecological issues of which related to human or humanity.

- The materials of eco-English use literary works.

- The materials of eco-English must contain engaging tasks.

- The materials of eco-English must have clear learning instructions on English skills or components and ecology awareness or conservation.

\section{Areas of Developing Eco-English Materials}

The areas of eco-English teaching materials on Eco-ELT are solely taken from products of literary works. These are not limited to: the odes, tales, stories, poems, pastorals, folkloric songs, novels, folklore, films, movies, video clips, scripts of plays or drama, scripts of theater, textbook, nature writing, lyrics of modern songs, and so forth. Of which basically they are under the newborn of Ecocriticism study. 


\section{Conclusion}

The study of Ecocriticism welcomes new born of ecocritical views in which to find ways of adding an environmental dimension in the respective disciplines, and education is no exception. Thus, the researcher proposes a new combination of interdisciplinary study called Eco-ELT. Of which it is from the combination study of ecology in literature and English Language Teaching (ELT). Guided with two aims of research (1) to explore the concepts of Ecocriticism and English Language Teaching (ELT) by giving theoretical elaborations on each of the study and (2) to give examples of practical applications of Eco-ELT in lesson plans and teaching materials, the concepts and applications of Eco-ELT are born.

The concepts of Eco-ELT are found grounded by the uses of literary works in English language teaching. The English literary works such as poetry, novels, short stories, folklore, films, video clips, scripts of plays or drama, scripts of theatre, textbook, nature writing, traditional or modern songs can become catalysts to evoke the messages of Ecocriticism study; embedding the virtues of loving the nature or Mother Earth to the human beings. Using the presence of ecocritical teaching, the ecological issues of the literary works are then can be coined with the instructional teaching materials in the classroom. They are applied in the whole activities of teaching learning process as reflected in lesson plan. They are also selected and designed as supplementary or compulsory English teaching materials. By which teachers can teach not only the grammatical and language features of literary works but also discuss the issues of environmental crisis and the necessity of saving the nature to the students.

Above all, of those essential findings, Eco-ELT is expected to create "green" moral agents in education settings (English teachers). By which English is used not only as a medium to overcome language barriers and boosting language competence of people, but also address ecological issues within social humanity matrix.

\section{References}

Glotfelty, C. (1996). The Ecocriticism Reader: Landmarks in Literary Ecology. Athens: the University of Georgia Press.

Bahador, R., \& Faghfori, S. (2014). Ang. J 3 pp. 315-322

Garrad, G. (2004). Ecocriticism: New Critical Idiom. London: Routledge.

Haycraft, J. (1978). An Introduction to English Language Teaching. Essex: Longman Group Ltd.

Murray, D E \& Cristison, M. (2011). What English Language Teachers Need to Know Volume II: Facilitating Learning. New York: Routledge.

Haynes, A. (2007). 100 Ideas for Lesson Planning. New York: Continuum International Publishing Group. 


\section{Appendices}

\section{Example of Eco-ELT Lesson Plan}

Here is the simple form of lesson plan.

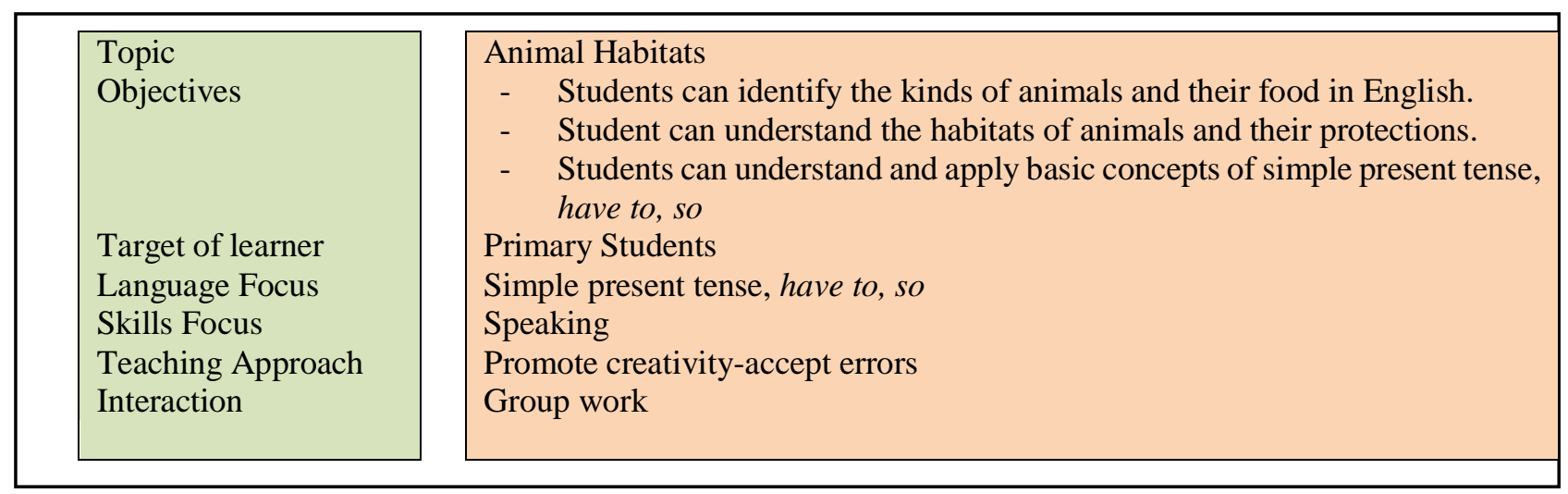

\section{Preparation}

- Teacher plays a short story video about animal and its habitat.

- Teacher draws three columns on the board as seen in box 1 .

\section{Procedure}

1.Teacher divides students into small groups, and asks them to watch a short story video about animals and its habitat.

2. The students are then asked to identify the kinds of animal, the kinds of food, and their habitats based the video.

3. The students are also asked to think of what sorts of protections they propose to save the animals and their habitats in a real life.

4. Teacher then asks the groups to jot it down their findings of identification and discussions in a piece of paper as seen in the box 1 .

\section{Assessment}

1. The groups' paper findings are exchanged one another.

2. Teacher then play a short story video about animal and its habitat once again.

3. Teacher then discusses the answers and the recommendations of animal and habitat protections with the students.

\section{Follow up}

1.Teacher ask the students about the basic use of simple present, have to, and so based the learning discussions of the Animal habitats

2. Teacher explains basic function of simple present, have to, and so

3. Teacher asks the students to explain the messages of today's learning activities on topic of animal habitats 


\section{Box 1}

\begin{tabular}{|c|c|}
\hline Kinds of animals found the video & Sentence Stems \\
\hline 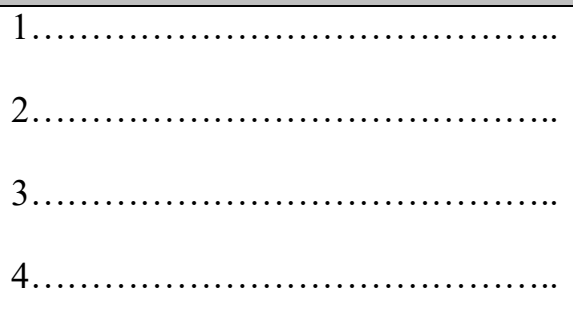 & $\begin{array}{l}\text { A.......lives in........., so we have to draw............ } \\
\text { A.......eats......., so we have to draw................. } \\
\ldots \ldots \ldots . . . \text { eat........, so they have to hide in............. } \\
\text { A..........sleeps in a..........., so we have to draw... }\end{array}$ \\
\hline \multicolumn{2}{|r|}{ Animals and Habitat Protections } \\
\hline Recommendations: & \\
\hline
\end{tabular}




\section{Example of Eco-English Teaching Materials}

Here is the example of Eco-English material (Eco-Poem). This is devoted to students in secondary or university level.

\section{A Poison Tree \\ By Willam Blake \\ 1974}

I was angry with my friend:

I told my wrath, my wrath did end.

I was angry with my foe:

I told it not, my wrath did grow.

And I watered it in fears,

Night and morning with my tears;

And I sunned it with smiles,

And with soft deceitful wiles.

And it grew both day and night,

Till it bore an apple bright.

And my foe beheld it shine.

And he knew that it was mine,

And into my garden stole

When the night had veiled the pole;

In the morning glad I see

My foe outstretched beneath the tree.

Source: http://www.poemhunter.com/poem/a-poison-

\section{Question Card}

Instruction: In groups, discuss and answer these questions

1. What is "the Poison Tree" all about?

2. What are the virtues of local wisdoms revealed in "the Poison Tree"?

3. What are the ecological issues revealed in "the Poison Tree"?

4. What are the roles of human beings to deal with the ecological issues revealed in "the Poison Tree"? 